\title{
Archival Preservation: Definitions for Improving Education and Training
}

by PAUL CONWAY

\section{INTRODUCTION}

In 1956, when librarians were just beginning to realize the enormity of the preservation task before them, Edward Lathem sought to focus a discussion on education and training by asking, "What should the conservation officer be expected to know?". His answer, that they "should, in substance, know as much as possible about as much as possible", remains as true today as it was over 30 years ago.'

Archival preservation is a central management function for archives, libraries, museums, and other institutions whose purpose is to acquire and make available cultural resources of long-term value. The organizational aspects of archival preservation have grown more complex and sophisticated as our understanding of the technical issues has sharpened. This complexity places a responsibility on educators in a variety of settings to develop equally sophisticated programs. The key problem seems to be that the development of innovative educational programs has fallen far behind the progress in developing a consensus on what constitutes the preservation challenge. Why this has happened and what could be done about it are the subjects of this article.

The literature in English on preservation and conservation has grown steadily in the last decade. Recent annotated bibliographies and compendiums document an increasing thirst for practical advice and technical research. ${ }^{2} \mathrm{~A}$ thorough review of this literature is outside the scope of this article. Instead, it will highlight key milestones of opinion toward a consensus on the preservation challenge, propose a three-part definition of archival preservation, and review some of the most important issues in education and training for archival preservation in the United States today.

\section{Definitions of Preservation and Conservation}

One distinguishing characteristic of an evolving field of specialization is disagreement on key definitions. In 1980, Pamela Darling \& Sherelyn Ogden ${ }^{3}$ 
reported that "no working consensus has yet emerged within the library profession" on what the terms "preservation" and "conservation" mean, and used the terms interchangeably throughout their review. Since that time, librarians and archivists appear to be approaching the needed consensus on a set of definitions with wide applicability to practice and education. For example, John Baker writes in the ALA World Encyclopedia":

Conservation seems more specific and object-oriented, whereas preservation is a broader concept that embraces conservation as well as protection, maintenance, and restoration in its meaning. It also carries the connotation of official policy and perhaps for that reason is the preferred term to describe the entire constellation of administrative and technical activities that bear on collection mangement in libraries and archives.

\section{The managerial aspect}

Howard Lowell ${ }^{5}$ defined the issue in similar terms for archivists in his major study of preservation needs in state archives:

Prescrvation is considered broadly to encompass any action that prevents, retards, or arrests deterioration or damage to state archives holdings through controlling the environment, proper housing, and preventive care. "Preservation" includes: program planning; surveying and improving storage and collection conditions; conservation treatments; and transferring information from a deteriorating physical medium to one that is more stable. "Conservation" in this report is defined to mean laboratory treatments that stabilize an item to maintain it in anchanging and usable condition, or actions taken to return a deteriorated or damaged document as nearly as possible to its original form or function with minimum further sacrifice of aesthetic and historic integrity.

Despite some reservations, European and American archivists appear willing to adopt "preservation" as the all-encompassing term. In a lecture to British archivists, David Vaisey ${ }^{6}$ notes that

we are all coming to realize that, having accepted that we are all in the conservation business, and having set about trying to make it a central part of our activities as collectors and providers of historical information, what we are all engaged in is, in fact, preservation.

He goes on to paraphrase and support the Research Library Group's statement on preservation.

The goal of preservation programs should be the maintenance of all library and archive materials in good condition either in their original format or in reproduction, to allow the researcher continued access. ${ }^{6}$ 
The International Federation of Library Associations and Institutions (IFLA) has recently issued a revision of their 1979 principles for preservation and conservation $^{7}$ that places both managerial and technical issues under the umbrella term "preservation".

Librarians and archivists have not always been as perceptive on preservation matters. In the decades before the Second World War, archivists blithely sidestepped the development of overt preservation strategies, largely because they perceived the entire scope of their duties as preservation, by definition. Contemporary manuals on the care and handling of archival materials ${ }^{8}$ viewed as sufficient the removal of archives and personal papers from damp basements, barns, and attics, their storage in (possibly equally damp) archive buildings, and the establishment of a semblance of order. Julius Grant, ${ }^{9}$ speaking for the library community in 1937, prematurely saw a new panacea in permanent paper. Preservation

is a matter which, fortunately perhaps, does not concern us at the moment, and the paper technician of today, continually striving to endow his product with a greater and greater degree of permanence, will never know whether he has saddled posterity with a blessing or a curse in disguise.

Through most of the post-war decades, archivists continued to define preservation in terms of holdings maintenance and environmental control of entire collections. They de-emphasized the treatment of individual items as impractical at best and counterproductive at worst. Until the 1983 publication of a basic manual incorporating both technical and administrative issues, ${ }^{10}$ physical and chemical treatments largely escaped their attention.

\section{$A$ hierarchy}

Christopher Clarkson," a highly respected conservator of medieval manuscripts and books, has another view of the relationship of preservation and conservation that emphasizes the degree of technical intervention.

By preservation we mean prevention of damage both physical and chemical. We use the word conservation to refer to the specialized process of making safe, or to a certain degree usable, fragile period objects. Restoration expresses rather extensive rebuilding or replacement by modern materials within a period object, catering for a future of more robust use. To generalize then, restoration implies major alterations, conservation minimal, and preservation none.

Clarkson is certainly correct to develop a hierarchy of technical processes. To 
define preservation solely in technical terms, however, underestimates the dynamic administrative activities within archival and library organizations. Preservation from an administrative, rather than technical perspective, is anything but passive, as Pamela Darling ${ }^{12}$ points out:

Administration involves planning, decision-making, evaluation, and supervision. Accurate information is crucial to the success of each activity.

A full definition of preservation activities in libraries, archives, and museums must encompass both administrative and technical activities that should be present in any institution with a preservation mandate.

\section{Interdisciplinary cooperation}

George Cunha ${ }^{13}$ provides part of the description in his "tripartite" concept of preservation, which involves close cooperation and communication among custodians who administer programs, scientists who develop new technical knowledge, and conservators who apply that knowledge. Mary Lynn Ritzenthaler ${ }^{14}$ expands Cunha's concept by combining cooperation with responsibility for the administration of archives:

Archival preservation, under optimal conditions, would be a responsibility shared by the scientist/ researcher, conservator, and archivist/curator, each contributing specialized knowledge to solve the problem at hand.

She acknowledges that the optimum is not typical:

In most archival settings it is the archivist alone who must make informed decisions regarding the material nature of collection items and their proper storage environment, as well as cstablish treatment options and priorities.

\section{A synthesis}

These and many other statements in the last decade make it possible now to propose a three-part definition of archival preservation that synthesizes leading opinions in the archival and library literature. It could serve both as a basis for building and evaluating preservation programs in institutions and as a foundation for enhanced education programs in a variety of settings. Part one is a statement of general philosophy. 
Archival preservation is the acquisition, organization, and distribution of resources (human, physical, monetary) to ensure adequate protection of historical and cultural information of enduring value and access for present and future generations.

When preservation is considered to be a central management responsibility, nearly every archival function in some way contributes to the preservation of historical materials. Therefore, the second part of a working definition is a statement of a conceptual structure that suggests how preservation activities may be organized.

Archival preservation encompasses planning and implementing policies, procedures, and processes that together prevent further deterioration or renew the usability of selected groups of materials.

Two underlying dimensions are present in this statement. The first distinguishes between the two basic aspects of the management function: planning and implementation. The second dimension reflects the distinction between activities that prevent or significantly retard deterioration from those that address damage that has already occurred. The wide variety of recommended activities may be placed into this two-dimensional matrix.

The task of educating librarians and archivists to build preservation programs, and evaluate them, is too large to be accomplished without assigning priorities and values to required activities. ${ }^{15}$ Thus there is a need for a third component of a comprehensive definition.

Archival preservation, when most effective, requires that planning precede implementation, and that prevention activities have priority over renewal activities.

Within this context, archival preservation is a major cultural responsiblitity. Guy Petherbridge ${ }^{16}$ writes that:

the perpetuation of society as we are accustomed to conceive or idealize it is dependent to a very large extent on the preservation en masse of our accumulated group memories and consciousness stored in the form of the written, printed and otherwise recorded word or symbol.

The technical and administrative information needed to create realistic, viable preservation programs is available. The question at hand is to understand how this information is acquired and used to build a preservation capacity. It is at this juncture that the "information problem" identified by the preservation community comes head-to-head with the classic management problems of information acquisition and use identified by the students of decision-making and information communication theory. We need to understand the percep- 


\section{Definitions for Improving Education and Training}

tions of those most directly responsible for using information to carry out their prescrvation mandate and to develop ways to change those perceptions as needed. Education and training are at the center of these processes.

\section{Responsibilities for Managing Preservation}

Archival preservation, from this perspective, is not a new issue. Over 40 years ago, Pelham Barr ${ }^{15}$ described a preservation program with such perception that it could serve today to define the scope of a modern, comprehensive approach. In 1979, Robert Patterson ${ }^{17}$ laid out a model charge to an academic library prescrvation committee that expanded on and yet retained the essence of Barr's ninc-point program. Authors since then have largely tinkered with four-decade old formulas.

The evolution of the full acceptance of preservation as an administrative function, however, has been documented in a series of conferences held to focus national attention. In gencral, the conferences have tended to concern either technical or administrative issues, rarely on both areas in equal depth. Conferences designed to mobilize professional or public sentiment on preservation issues are the most relevant to the problem of defining educational and training needs. $^{18}$

When Darling \& Ogden ${ }^{3}$ reviewed the findings of some of these conferences in 1980, they were uncomfortable making statements about the late 1970s. With an additional decade between their analysis and present conditions, it is clear that 1978 was a watershed in the development of a consensus on preservation management. The Report of the Study Committee on Libraries and Archives: National Needs in Libraries and Archives Conservation ${ }^{19}$ marked the beginning of cooperation between leading archivists and librarians. While Darling \& Ogden recognized the importance of this report, they were not in a position to foresee the degree to which it represented a national agenda that has been amplified by subsequent conferences and reports.

Among the two most significant conferences were the Allerton Park Institute, sponsored by the University of Illinois, Graduate School of Library and Information Science, November 15-18, 1981; and an American Library Association (ALA) conference that focused specifically on the library preservation program, April 29, 1983. At Allerton Park, conference participants werc urged to follow the lead of archivists and rare book curators in designing preservation programs. "One of the most important views I can impart to you", said Robert Patterson, ${ }^{20}$ "is that preservation is a library-wide concern, and that librarians must be the persons who will develop preservation programs". While acknowledging that preservation is a highly technical matter and that there is currently 
a severe shortage of trained conservators, Patterson claimed that "librarians must take the responsiblity for educating themselves about conservation. They must educate themselves to the point that they can design and implement their own programs."

By 1983, participants in the ALA conference could draw on the experience of a number of academic libraries in designing and implementing preservation programs. Rutherford Rogers ${ }^{21}$ contended, however, that too much weight may have been placed in the past on national planning efforts. Pay attention to local needs, he suggested, for a national planning effort

cannot supplant local programs or relieve us of our responsibjlity to develop them. Instead, we must take advantage of the large support network of collective research and educational activities... to develop local programs suited to local needs, a network that may serve as the basis of a true national program.

In reviewing progress made in the last two decades, Sally Buchanan ${ }^{22}$ now believes that archivists and librarians are at a critical juncture:

It seems time to develop a vision for the future which assumes that the basic task is accomplished that of convincing and educating the profession about the legitimacy of preservation/conservation:

Nevertheless, she puts education at the front of her agenda for the next decade, as the principal means of fostering collaboration and integration:

Integration into the mainstream of budgeting, collection management, access, service, and personnel concerns can only enhance the status and complete the acceptance of preservation/conservation as a legitimate and continuing part of the library/archival profession.

\section{Edugation for Preservation Responsibility}

The role of education and training in developing in practitioners the foundation of knowledge, skills, and attitudes has long been recognized as central. Yet the continuous discussion of specific approaches to the educational process that are appropriate for preservation reflects the impoverished nature of the entire educational system. Failure to act fully on an agenda that has been on the table for many years has resulted in educational offerings that are too narrow in scope and too limited in availability to meet the broad training needs of the library and archives professions. 


\section{The general approach}

While Edward Lathem' first called attention to the comprehensive educational needs demanded by the preservation challenge over 30 years ago, over half of this period elapsed before the first major statement appeared in print that translated his broad mandate into operational terms. In 1972, Warren J. Haas, ${ }^{23}$ under the auspices of the Association of Research Libraries, prepared a comprehensive overview of a national system for the preservation of library materials. His statement contained a four-part program for widespread education and training. First, he suggested that a series of traveling exhibitions bring the preservation problem to the attention of the general public. Second, research findings should be widely disseminated to library administrators. Third, a fundamental training program should be developed for library technical and clerical staff, including film and printed materials. Finally, Haas called for a regionally based apprenticeship program to train technical staff for archive and library conservation.

Haas' pioncering proposal remains an important and vital document for at least three reasons. First, he conceived of librarians and archivists as united in the challenge of preservation. "The preservation problem is in the end a social problem", he writes. Education for preservation, therefore, need not be bound to a single discipline. Second, Haas reaffirmed that access is the fundamental purpose of preservation. Education for preservation, therefore, requires a firm understanding of users and uses of cultural materials. Third, and most important for the design of comprehensive educational programs, Haas saw educational efforts proceeding from the general to the specific. Public awareness and support necessarily precede technical training. Similarly, broad-based training for the entire professional community precedes the exclusive development of conservators. At several places in his plan, Haas reaffirmed the necessary local and regional focus of preservation planning and educational efforts.

\section{Specialists}

Since Haas wrote, a polarity has emerged on the philosophical approach to education for preservation. Paul Banks ${ }^{24}$ represents what could best be described as the specialized, top-down, or elite approach. In a major position paper on the subject during a planning conference for a national preservation program, he expressed the view that the number one priority should be the training of a cadre of highly skilled paper conservators who could then chart the future course of conservation. Acknowledging that there is also a pressing 
need for conservation administrators, technicians, and heightened awareness generally, he nevertheless felt strongly that:

because nearly every aspect of conservation involves complex, technical issues, none of these worthy ends can be met effectively without the availability of thoroughly trained conservators. It would be like trying to provide health care without the physicians.

Banks acted on his own recommendation by establishing the first and as yet only full academic training program for conservators and preservation administrators.

George Cunha ${ }^{26}$ best represents the generalized, local/regional, mass approach to education for preservation. Cunha has faith in the ability of archivists and librarians to improvise local solutions to conservation:

For some strange reason the idea has developed that those responsible for records, although able to handle the many other aspects of their work, are not competent to manage this important aspect of their work.

By way of emphasis, he declared that:

I cannot accept the suggestion made by a professional paper conservator in a recent professional journal that "except for providing optimum environment and storage conditions, it is better to let damaged materials go untouched than to let anyone other than a professional conservator treat them".

Cunha put his philosphy to work in helping establish and direct the Northeast Document Conservation Center (NEDCC), which seeks to provide treatment services as well as consulting and educational programs to an entire region of the United States. Until recently, NEDCC was the only institution of its kind. Yet it has managed to become a model for the potential of regional cooperation. ${ }^{27}$

\section{Information and communication}

Pamela Darling ${ }^{12}$ represents the middle ground between the grassroots/do-ityourself approach and the experts-only approach. In one of her most important writings on the subject of preservation administration, she draws conclusions from a series of personal observations. Her views have important implications for anyone attempting to transcend the limitations of current educational offerings. First, she observes that mistrust and inadequate communication 
between technicians and administrators have delayed the development and application of new techniques. Second, she believes that cooperative approaches to preservation at too early a stage can actually retard progress. Third, she places great emphasis on vision and inspired leadership, but recognizes that senior leaders are seldom in a position to devise the practical methods and routines of working programs. Finally, she cautions that we ignore the preservation problems of non-paper materials at our own peril. The primary issue for administrators, and by implication for educators, is one of information creation and dissemination:

The major obstacle to the development and administration of preservation programs is the shortage, not of money, as many suppose, but of knowledge. Financial contraints are serious and will become more so; but until the preservation field reaches the point at which most people know what ought to be done and how it should be done, the lack of money to do it on a scale appropriate to the need is not terribly significant. The preservation administrator, therefore, must spend a great deal of time seeking, sorting and analyzing information.

When Darling expressed these views seven years ago, the literature of preservation was just beginning an explosive growth that continues unabated today. In addition, the educational efforts she and others described at the beginning of the decade are well established. Useful information on preservation administration is now more widely available, innovative programs are in place around the United States, and formal and informal training programs are available for those who can afford them. ${ }^{28}$ Whether or not they are sufficient in number to accomplish the training needs of the library and archives community is only part of the issue. The striking fact remains that Darling's comments still describe the situation in most libraries and archives today, despite the availability of information, advice, and educational opportunities.

\section{Where Do We Go From Here?}

To make the most progress, the key actors in the preservation education arena faculty and adjunct instructors in library schools, directors of professional associations, leading library preservation administrators, and technically trained conservators - will need to lead the library and archives profession toward cooperative educational undertakings in a variety of settings. Priority should be given to three areas: research and development, training for educators, and a national conference on educational needs.

Active research and development on the central administrative issues of archival preservation is badly needed. It is commonly accepted that research 
advances on technical issues, such as cellulose fiber deterioration, paper strengthening, mass deacidification, microform image permanence, properties of magnetic media, and the impact of microenvironments on stored materials, have a direct impact on the development of a national agenda. Similar applied research is needed on such central issues as how archivists and librarians acquire and use information to build preservation programs, administrative structures that promote the efficient dissemination of information within organizations, the relationship of technical knowledge to administrative ability, and how planning and program evaluation interact in the preservation context. Findings from studies in a variety of institutional settings should be consciously integrated into educational offerings as models or case studies.

Significantly greater resources should be devoted to building a cadre of people qualified to teach archivists, librarians, and others about archival preservation. While there will probably never be a single forum for education and training (library schools, continuing education, and on-the-job training are all appropriate), conscious effort must be made to equip seasoned administrators with the skills, the curriculum guides, the incentives, and the opportunity to share their knowledge with others. Appropriate strategies toward this goal may include training institutes for instructors, regional seminars, published examples of course syllabi and supporting materials, and guides for planning and implementing on-the-job programs.

In 1978, the National Conservation Advisory Council ${ }^{19}$ identified this problem in calling for a national conference of conservators, educators, archivists, and librarians similar to the conferences held for museum conservators in 1958 and 1973. No such conference has taken place and the time is ripe to convene one. A national conference in 1991 on educational needs in preservation would mark the thirty-fifth anniversary of Edward Lathem's call to comprehensiveness. Such a conference could chart progress made to date, summarize current curriculum needs, assess the resources available in universities, professional associations, and institutions, and set priorities to carry the professions through to the twenty-first century.

In the full generation since Pelham Barr called for "responsible custody" and Edward Lathem called for comprehensive knowledge about preservation matters, a virtual revolution has been worked in the United States on attitudes toward preservation. The library and archives professions have been mobilized, the general public is being made aware of the urgency of the problem, and politicians and opinion leaders appear far more willing to entertain the notion that preserving cultural resources is a national responsibility. We are poised for the next "age of enlightenment", as Lathem referred to his era. That age should build on the progress made to date in developing a consensus on the definition 


\section{Definitions for Improving Education and Training}

of the preservation challenge to form a similar consensus on solutions to its educational requirements.

\section{Summaries}

\section{Archival Preservation: Definitions for Improving Education and Training}

Archival preservation is a central management function for archives, libraries, museums, and other institutions whose purpose it is to acquire and make availablc cultural resources of long-term value. This article traces the emergence of a consensus on what constitutes archival preservation, offers a three-part definition of the concept, and discusses the major opinions in the United States on the nature of education for archival preservation. The author concludes with recommendations on how to focus attention on education and training needs.

\section{La Préservation Archivistique: Définitions pour l' Amélioration de l'Éducation et de la Formation}

La préservation archivistique est une fonction centrale de la conduite des archives, des bibliothèques, des musées et d'autres institutions, dont le but est d'acquérir et de inettre à disposition des ressources culturelles d'une valeur à long terme. Cet article trace l'apparition d'un consensus sur ce qui constitue la préservation archivistique, il donne une définition tripartite de la notion même, et il discute enfin les avis majeurs aux États-Unis concernant la nature de l'éducation en matière de la préservation archivistique. L'autheur conclut en donnant des conseils sur la manière d'attirer l'attention sur les besoins d'éducation et de formation.

\section{Konservierung: Definitionen zur Verbesserung der Ausbildung}

Konservierung ist eine zentrale Aufyabe von Archiven, Bibliotheken, Museen und anderen Institutionen, deren Aufgabe es ist, Gegenstände, die unserc Kultur darstellen, zu sammeln und langfristig aufzubewahren und zugänglich zu machen. Der Aufsatz zeigt die Entwicklung einer allgemein akzeptierten Auffassung auf, worin Konservierung in Archiv und Bibliothek besteht und schlägt cine dreigliedrige Definition vor. Sodann werden die wichtigsten Meinungen in den U.S.A. diskutiert, wie die Ausbildung zu dieser Disziplin beschaffen sein muß. Den Abschluß bilden Empfehlungen, wo hierin Schwerpunkte zu setzen wären.

\section{REFERENCES}

1. Lathem, E.: Some personnel considerations for binding and conservation services. Library Trends 4 (1956): 321-34.

2. Montori, C. J. \& Longstreth, K. E.: The preservation of library materials, 1987: a review of the literature. Library Resources and Technical Services 32 (1988): 235-47. 
Montori, C. J.: Library preservation in 1986: an annotated bibliography. Library Resources and Technical Services 31 (1987): 365-85.

Fox, L.: A two year perspective on library preservation: an annotated bibliography. Library Resources and Technical Services 30 (1986): 290-318.

Morrow, C. C. \& Schoenly, S. B.: A conservation bibliography for librarians, archivists, and administrators. Troy, NY: Whitston Publishing, 1979.

3. Darling, P. W. \& Ogden, S.: From problems perceived to programs in practice: the preservation of library resources in the U.S.A., 1956-1980. Library Resources and Technical Services 25 (1981): 9-29.

4. Baker, J. P.: Conservation and preservation of library materials. In: ALA World Encyclopedia of Library and Information Services, second edition. Chicago: American Library Association, 1986: 219-22.

5. Lowell, H.: Preservation needs in state archives. Albany, NY: NAGARA, 1986: 8-9.

6. Vaisey, D.: Archivists, conservators, and scientists: the preservation of the nation's heritage. The Maurice Bond Memorial Lecture, 1987. Archives 28 (1988): 131-43.

7. Dureau, J. M.: Principles for the preservation and conservation of library materials. The Hague: IFLA, 1986.

8. Fitzpatrick, J. C.: Notes on the care, cataloguing, calendaring and arranging of manuscripts. 3rd ed. Washington, DC: Library of Congress, 1928; see also Nute, G.: The care and cataloguing of manuscripts. St. Paul: Minnesota Historical Society, 1936.

9. Grant, J.: Books and documents: dating, permanence, and preservation. London: Grafton \& Co., 1937.

10. Ritzenthaler, M. L.: Archives and manuscripts: conservation. Chicago: Society of American Archivists, 1983.

11. Clarkson, C.: Conservation priorities: a library conservator's view. In: Petherbridge, G., ed. Conservation of library and archive materials and the graphic arts. London: Butterworths, 1987: 235-6.

12. Darling, P. W.: Creativity $v$. despair: the challenge of preservation administration. Library Trends 30 (1981): 179-88.

13. Cunha, G. M.: Tripartite concept of conservation. In: Morrison, R. C. Jr., Cunha, G. M. \& Tucker, N. P., ed. Conservation administration. Boston: NEDCC and Boston Athenaeum, 1975: $19-43$.

14. Ritzenthaler, Conservation (ref. 10): 9.

15. Patterson, R. H.: Organizing for conservation. Library Journal 104 (1979): 1116-9.

16. Petherbridge, G.: Conservation of library and archive materials and the graphic arts. London: Butterworths, 1987: 1-12.

17. Barr, P. Book conservation and university library administration. College and Research Libraries 7 (1946): 214-19.

18. A series of major conferences on technical matters, however, have had a significant impact on preservation planning efforts. See especially Permanent/Durable Book Paper: summary of a conference held in Washington, D.C., September 16, 1960. Richmond, VA: Virginia State Library (1960); Williams, G. R.: The preservation of deteriorating books: an examination of the problem with recommendations for a solution. Washington, DC: Association of Rescrach Libraries (1964); Winger, H. W. \& Smith, R. D., eds. Deterioration and preservation of library materials. Chicago: University of Chicago Press (1970); Williams, J. C. ed., Preservation of paper and textiles of historic and artistic value. Advances in Chemistry Series 164. Washington, DC: American Chemical Society, 1977. Williams, J. C. ed., Preservation of paper and textiles of historic and artistic value II. Advances in Chemistry Series 193. Washington, DC: American Chemical Society, 1979.

19. National Conservation Advisory Council: Report of the Study Committee on Libraries and Archives: national needs in libraries and archives conservation. Washington, DC: NCAC, 1978: 45.

20. Patterson, R. H.: Conservation: what we should do until the conservator and the twenty-first century arrive. In: Henderson, K. L. \& Henderson, W. T., eds. Conserving and preserving library materials. 
Urbana-Champaign, IL: University of Illinois, Graduate School of Library and Information Science, 1983: 10-11.

21. Rogers, R. D.: Library preservation: its scope, history, and importance. In: Merrill-Oldham, J. \& Smith, M., eds. The library preservation program: models, priorities, possibilities. Chicago: American Library Association, 1985: 7-20.

22. Buchanan, S. A.: The third decade: directions for preservation conservation. Conservation Administration News 33 (1988): 3, 10.

23. Haas, W. J.: Preparation of detailed specifications for a national system for the preservation of libran materials. In: Baker, J. P. \& Soroka, M. C., eds. Library conservation: preservation in perspective. Stroudsburg, PA: Dowden, Hutchinson \& Ross, 1978: 413-41.

24. Banks, P. N.: Education of paper conservators in a national preservation program. In: A national preservation program: proceedings of the Planning Conference. Washington, DC: Library of Congress. Preservation Office, 1980: 53-5.

25. Banks, P. N.: Education in library conservation. Library Trends 30 (1981): 189-201.

26. Cunha, G. M. et al.: The conservation and preservation of historical records. American Archivist 40 (1977): 321-4.

27. Russell, A., Motylewski, K., \& Tracy, G.: NEDCC: a leader in preservation. Library Resources and Technical Services 32 (1988): 43-7.

28. Morrow, C. C.: The preservation challenge: a guide to conserving library materials. White Plains, NY: Knowledge Industry Publications, 1983.

Paul Conway

Preservation Program Officer

Society of American Archivists

600 S. Federal, Suite 504

Chicago, IL 60605

USA

60 